\title{
Cytotoxicity of triterpenoids-enriched extracts from bark of Eucalyptus nitens against colorectal HCT116 cancer cells
}

\author{
C Calçada $\stackrel{1}{1}$, J Pereira $\stackrel{1}{*}$, RMA Domingues $\stackrel{2}{-}$, AJD Silvestre $\stackrel{2}{-}$, F Duarte $\stackrel{3}{-}$, C Pereira-Wilson $\stackrel{1}{*}$, \\ CF Lima 1 \\ - $\quad{ }^{1}$ CITAB, Department of Biology, University of Minho, Braga, Portugal \\ - ${ }^{2}$ CICECO, Department of Chemistry, University of Aveiro, Aveiro, Portugal \\ - ${ }^{3}$ CEBAL, Beja, Portugal
}

Eucalyptus nitens crops are used in Portugal mainly by the pulp and paper industries, producing substantial bark residues with no added value use [1]. They can, however, be an interesting source of bioactive triterpenic compounds. Here, a lipophilic crude extract (CE) from bark of $E$. nitens prepared with dichloromethane [1] with about $70 \%(\mathrm{w} / \mathrm{w})$ of triterpenoids, and a fraction of this (F2) more enriched in triterpenoids $(93 \% \mathrm{w} / \mathrm{w})$, as well as their main compounds betulinic acid (BiA) and betulonic acid (BoA), were used to determine their potential cytotoxicity against the colorectal HCT116 cancer cells. After $48 \mathrm{~h}$ of incubation, the extracts/compounds inhibited significantly cell growth in a concentrationdependent manner (assessed by the MTT assay), with a GI50 s of $1.3 \mu \mathrm{g} / \mathrm{mL}$ and $2.2 \mu \mathrm{g} / \mathrm{mL}$ for $\mathrm{F} 2$ and $\mathrm{CE}$ extracts, respectively, and of $0.8 \mu \mathrm{M}$ and $3.9 \mu \mathrm{M}$ for $\mathrm{BoA}$ and $\mathrm{BiA}$, respectively. The inhibition of cell growth was shown to be dependent on both the arrest of cell cycle at the G2/M phase, and the induction of cell death (assessed by PI staining). At the higher concentrations tested (up to $25 \mu \mathrm{M}$ ), apoptosis was the major contributor to the observed cell death, and that was associated with JNK activation. Using the JNK inhibitor SP600125 and the pan-caspase inhibitor z-VAD, apoptosis induced by the extracts/compounds was shown to be dependent on JNK and caspases activation. At intermediate concentrations of extracts/compounds, a delayed and non-apoptotic type of cell death was present, which was associated with a significant activation of AMPK and a decrease of p53 levels. Altogether, these results demonstrate that the wasted bark of E. nitens can be used as a potential source of interesting cytotoxic natural triterpenoids against cancer cells.

Acknowledgements: CMC is supported by UMINHO/BI-M/PTDC_AGRFOR_3187_2012/2013 grant. This work is supported by FCT research grant NEucBark (PTDC/AGR-FOR/3187/2012), co-funded by COMPETE (QREN) and European Community fund FEDER.

Keywords: Eucalyptus nitens, bark extracts, triterpenoids, HCT116 cancer cells, cytotoxicity, apoptosis, cell cycle arrest

References: 
[1] Domingues RMA, Sousa GDA, Silva CM, Freire CSR, Silvestre AJD, Pascoal-Neto C (2011). High value triterpenic compounds from the outer bark of several Eucalyptus species cultivated in Brazil and in Portugal. Industrial Crops and Products 33: $158-164$. 